\title{
Adjuvant Endocrine Therapy for Hormone-positive Breast Cancer, Focusing on Ovarian Suppression and Extended Treatment: An Update
}

\author{
DANIEL GLASSMAN ${ }^{1}$, SUE HIGNETT ${ }^{1}$, SHAZZA REHMAN ${ }^{2}$, RICHARD LINFORTH ${ }^{1}$ and MOHAMED SALHAB ${ }^{1}$ \\ ${ }^{1}$ Breast Surgery Department, Bradford Teaching Hospital NHS Trust, Bradford, U.K.; \\ ${ }^{2}$ Medical Oncology Department, Bradford Teaching Hospital NHS Trust, Bradford, U.K.
}

\begin{abstract}
The benefits of five years of adjuvant endocrine therapy for oestrogen receptor (ER)-positive early breast cancer are well established. However, recent evidence suggests that extended endocrine treatment and ovarian suppression in selected groups of patients have significant advantages. In this article, we review the current evidence for adjuvant endocrine therapy in breast cancer with focus on extended adjuvant endocrine therapy and ovarian suppression, and also highlight the advantages and disadvantages of these therapeutic strategies. A literature search was performed through PubMed, Medline, and Cochrane using the following search terms: Endocrine therapy, Tamoxifen, Anastrazole, Ovarian Suppression, Exemestane, Letrozole and STS Inhibitors. All available evidence for adjuvant endocrine therapy was reviewed and summarised to assess the current guidance and the progress of the management of patients with ER-positive breast cancer. Extended endocrine therapy should be tailored according to patient needs dictated by their individual risk factors, molecular type of breast cancer, menopausal status, comorbidities, life style and risk of recurrence. Clinicians ought to discuss with patients the pros and cons of different adjuvant endocrine therapy approaches and highlight the potential side effects and toxicity.
\end{abstract}

Variation in gene expression patterns within breast cancers has led to molecular profiling and classification of tumours.

This article is freely accessible online.

Correspondence to: Daniel Glassman, 14 Adel Green, Leeds, West Yorkshire, LS16 8JX, U.K. Tel: +447849084292, e-mail: dan.s.glassman@gmail.com

Key Words: Breast cancer, endocrine therapy, ovarian function suppression, extended adjuvant endocrine, review.
Breast cancer subtypes differ markedly in prognosis and in the therapeutic targets they express. The intrinsic subtypes can be categorized as oestrogen receptor (ER)-positive (Luminal A, Luminal B) and ER-negative (Basal, Her2) (1). In this paper we focus on ER-positive subtypes.

Luminal A, which account for approximately $40 \%$ of breast cancers are noted to have a good prognosis. They are strongly oestrogen-positive, progestogen-positive, with very low rates both of HER2 and proliferation-related gene expression. Luminal B, which account approximately for $20 \%$ of breast cancers, although ER-positive the expression of these receptors is much lower in comparison to Luminal A tumours. They also have a higher expression of the proliferation cluster and more variable HER2 expression. Ultimately, the prognosis of a patient with Luminal B breast cancers is worse than those with Luminal A cancers with an associated higher recurrence rate (1).

Many breast cancer patients are not offered adjuvant chemotherapy due to favourable clinical and pathological indicators or due to comorbidities. It is widely practiced that patients with ER-positive breast cancer are treated with 5 years of adjuvant endocrine therapy, with Tamoxifen or an aromatase inhibitor (AI) $(2,3)$. The 5-year disease-free survival (DFS) rates are increased whilst recurrence and breast cancer mortality rates have been reported in various studies to be significantly reduced with 5 years of Tamoxifen treatment (4). Sixty to seventy percent of breast cancer patients are found to be ER-positive and despite the proven benefits of adjuvant endocrine therapy, $66 \%$ of deaths and $50 \%$ of breast cancer relapses occur after the initial 5 years post-operative period having stopped Tamoxifen (3, 5-7). More recent evidence is emerging, which implies that ER-positive breast cancer is a chronic relapsing disease that may remain silent for many years (3). The high rate of late relapse was the basis of many recently reported studies examining the value of extended endocrine therapy in hormone receptor-positive breast cancer. 
In this article, we review the current evidence for adjuvant endocrine therapy in ER-positive breast cancer with a focus on extended adjuvant endocrine therapy and combining endocrine therapy with ovarian suppression, highlighting the advantages and disadvantages of these therapeutic strategies.

\section{Evidence for Five Years Endocrine Therapy}

In the adjuvant setting, Tamoxifen is well established treatment for women with hormone-sensitive disease. Tamoxifen is proven to have substantial disease-free and overall survival (OS) benefits. It can reduce rates of contralateral breast cancer $(8,9)$. The initial trials demonstrating the benefits of using Tamoxifen were NATO (10), CRC (11) and NSABP B-14 (12) (Table I). Furthermore, the continuing Early Breast Cancer Trialists' Collaborative Group (EBCTCG) overviews have provided definitive confirmation of the value of Tamoxifen, confirming the odds of recurrence and death were reduced by $47 \%$ and $26 \%$, respectively, after about 5 years of treatment (13-15).

The Oxford Overview reviewed women with a 15 year follow up of ER-positive breast cancer treated with Tamoxifen. In a meta-analysis of multiple trials they demonstrated a $13 \%$ reduction in breast cancer recurrence and $9 \%$ reduction in breast cancer mortality with a $38 \%$ reduction in contra-lateral breast cancer over 15 years, compared to patients that did not receive tamoxifen (6).

The ATAC trial (Tables II, III), in 2002 provided evidence supporting the use of Anastrazole, an AI, in postmenopausal women with early hormone-positive breast cancer when compared to Tamoxifen. Anastrazole treatment was associated with a $26 \%$ risk reduction of time to recurrence, a reduction in contra-lateral breast cancer and improved DFS compared to Tamoxifen, despite a similar OS to Tamoxifen $(14,16,17)$. Moreover, combination therapy was found to be equivalent to Tamoxifen alone and inferior to Anastrazole $(14,16,17)$. The trial results also suggested that there might be a carry-over effect beyond 5 years, similar to that of Tamoxifen, however, further evidence is required to support this conclusion $(14,16,17)$.

In 2009, the BIG 1-98 Collaborative Group (Tables II, III) recruited 8010 patients between 1998-2003 in a randomized double blind, phase III trial comparing Tamoxifen to the AI Letrozole in ER-positive postmenopausal women with early breast cancer. (18) They compared 5 years of monotherapy (Tamoxifen $v s$. Letrozole), or sequences (2 years Tamoxifen switching to Letrozole or vice versa). In 2005, the group reported that DFS was significantly greater in the Letrozole group than in the Tamoxifen group (Hazard ratio [HR] 0.81; 95\% confidence interval [CI], 0.70 to $0.93 ; p=0.003)$, especially the risk of distant recurrence (HR, 0.73; $95 \% \mathrm{CI}$, 0.60 to $0.88 ; p=0.001)$. Consequently, they identified a survival benefit in those patients switching from Tamoxifen to Letrozole vs. Tamoxifen monotherapy (19). This observation led the Monitoring Committee and the Study Collaborative to unblind the patients currently taking Tamoxifen and sanction crossover to Letrozole at the patient's choice. Twenty five percent of patients chose to cross over from Tamoxifen to either the extended or adjuvant Letrozole group (19). At 5 years the group had demonstrated a statistically significant reduction in 5 year distant disease recurrence $(89.7 \%$ Tamoxifen $v s .92 .4 \%$ Letrozole HR 0.8 [95\% CI 0.67-0.94]) and DFS (82.1\% Tamoxifen vs. 85.6\% for Letrozole HR 0.83 [95\% CI 0.74-0.94]). The difference in OS between monotherapy treatment (Tamoxifen vs. Letrozole) was not statistically significant $(90.9 \%$ Tamoxifen vs. 91.8\% Letrozole HR 0.82 [95\% CI 0.7-0.95]) but this could be due to the crossover in treatment following the unblinding $(18,19)$.

Switching from Tamoxifen to Letrozole after 2-3 years statistically significantly reduced the risk of local recurrence (29\%), distant recurrence (23\%), and death $(21 \%)$. Thus, the patients who crossed over following the unblinding received the most effective treatment (19) (Tables II, III, IV). However, neither switching Letrozole to Tamoxifen or vice versa were found to be superior compared to the DFS rates identified in the Letrozole monotherapy group (18).

The BIG 1-98 study concluded that post-menopausal women with early ER-positive breast cancer should undertake an AI as their adjuvant endocrine therapy either as monotherapy or switching from Tamoxifen (18). Both the ATAC trial and the BIG 1-98 trial found similar hazard ratios for DFS. In subgroup analyses of the ATAC trial, the benefit of Anastrazole was seen predominantly in patients who had not received adjuvant chemotherapy and those with nodenegative disease, whereas in the BIG 1-98 trial, the greatest benefit of Letrozole was in patients who had received chemotherapy and in those with node-positive disease (14, 19) (Table III).

Following the introduction of third generation AI (Tables III, IV), trials began to look at switching from Tamoxifen to an AI suggesting a reduction in recurrence rates and increased DFS (7). Another study is the Intergroup Exemestane Study (IES), which included 4,724 postmenopausal patients with early-stage breast cancer and demonstrated clinically important benefits from switching adjuvant therapy after 2-3 years of Tamoxifen to Exemestane. OS improvement was demonstrated, with 352 deaths in the Exemestane group versus 405 deaths in the Tamoxifen group. Risk of relapse or death was maintained for at least 5 years after treatment and was associated with a continuing beneficial impact on OS when switching to Exemestane compared with continuing on Tamoxifen (20). ABCSG trial and ARNO 95 combined to determine whether patients benefited from either 2 years or 5 years Tamoxifen 
Table I. Evidence for Tamoxifen.

\begin{tabular}{|c|c|c|c|c|}
\hline Year & Study & & $\begin{array}{l}\text { Median } \\
\text { follow-up }\end{array}$ & Outcomes \\
\hline 1988 & NATO (10) & $\begin{array}{l}1285 \text { women randomized } 10 \mathrm{mg} \text { bd } \\
2 \text { y } v s . \text { no treatment }\end{array}$ & $5.6 \mathrm{y}$ & $\begin{array}{l}36 \% \text { Reduction in risk of event } \\
29 \% \text { reduction in risk of death }\end{array}$ \\
\hline 1998 & $\begin{array}{l}\text { CRC Adjuvant } \\
\text { Breast Trial (11) }\end{array}$ & $\begin{array}{l}2230 \text { women randomized to } \\
\text { - Tamoxifen \& Cyclophosphamide } \\
\text { - Cyclophosphamide } 6 \text { days post op iv } \\
\text { - Tamoxifen } 2 \text { y } 10 \mathrm{mg} \text { bd } \\
\text { - No therapy }\end{array}$ & & $\begin{array}{l}\text { Effects of adjuvant Tamoxifen were similar } \\
\text { to those of adjuvant chemotherapy, } \\
\text { especially if tumour is ER-positive. } \\
\text { Excellent compliance, min side effects }\end{array}$ \\
\hline 1998 & NSABP B -14 (15) & $\begin{array}{l}2644 \text { women node-neg, ER-pos breast } \\
\text { cancer randomized to } \\
\text { - Tamoxifen } 10 \mathrm{mg} \text { bd } \\
\text { - Placebo }\end{array}$ & $15 \mathrm{y}$ & $\begin{array}{c}\text { RFS } 78 \% \text { vs. } 65 \% \\
\text { OS } 71 \% \text { vs. } 65 \% \\
\text { Women aged }<50 \&>60 \text { significant benefit, } \\
50-59 \text { no diff in OS but still improvement } \\
\text { in recurrence free survival. }\end{array}$ \\
\hline
\end{tabular}

Bd, Twice daily; Diff, difference; ER, oestrogen receptor; Neg, negative; Pos, positive; Y, year; RFS, recurrence free survival, OS, overall survival.

Table II. Evidence for AI Monotherapy

\begin{tabular}{|c|c|c|c|c|}
\hline Study & Patients & Detail & Follow-up & Outcome \\
\hline ATAC (14) & 9366 & $\begin{array}{l}\text { Double blind } \\
\text { AI then Tam } v s \text {. } \\
\text { Tam then AI }\end{array}$ & $\begin{array}{c}5 \mathrm{y} \\
(120 \text { months })\end{array}$ & $\begin{array}{c}\text {-AI improved DFS with AI } 89.4 \% \text {, reduced incidence of } \\
\text { contralateral breast cancer, sig reduction in recurrence rates, } \\
\text { HR 0.81 } \\
-26 \% \text { risk reduction with an AI } \\
\text {-Combination no different to Tamoxifen alone }\end{array}$ \\
\hline BIG 1-98 $(3,18)$ & 8010 & $\begin{array}{c}\text {-Letrozole } \\
\text {-Tam } \\
\text {-Letrozole then Tam } \\
\text {-Tam then Letrozole }\end{array}$ & $8.1 \mathrm{y}$ & $\begin{array}{l}\text { DFS improved with Letrozole. } \\
\text { Switching to Letrozole better DFS than Tam alone. } \\
\text { (Unblinded part way through) }\end{array}$ \\
\hline TEAM (38) & 9775 & $\begin{array}{l}\text {-Upfront Tam vs. Exemestane } \\
\text {-Sequential Tam to Exemestane } \\
\text {-Exemestane alone }\end{array}$ & $\begin{array}{l}2.75 \mathrm{y} \\
2.75 \mathrm{y} \\
5 \mathrm{y}\end{array}$ & $\begin{array}{l}\text { Improved DFS with Exemestane, no diff between } \\
\text { Exemestane alone or when switched to Exemestane }\end{array}$ \\
\hline
\end{tabular}

AI, Aromatase inhibitor; DFS, disease-free survival; Diff, difference; HR, hazard ratio; Tam, Tamoxifen; TTDR, time to distant recurrence; Y, year.

then switching to an AI (Anastrazole) (7) (Tables III, IV). They concluded switching at 2 years to an AI resulted in decreased recurrence rates in postmenopausal women. The hypothesis behind this was either Tamoxifen resistance or AI were more potent in reducing peripheral oestrogen concentrations (7).

\section{The Role of Ovarian Function Suppression in Adjuvant Treatment}

Ovarian function suppression (OFS) (Table V), as a form of treatment for breast cancer was first reported in 1896 in Scotland, where a surgeon demonstrated that a patient having undergone an oophorectomy reduced the size of her breast cancer (21). A meta-analysis performed by the Early Breast Cancer Trialists Collaborative Group (EBCTCG) in 1995 concluded that trials prior to the 1980s did suggest a reduced relapse rate and increased survival in women aged under 50 using ovarian function suppression (2). This benefit was noted to be sustained for up to 15 years (2). OFS is achieved either through surgery or chemically through the administration of gonadotrophin-hormone (GNRH) agonists. Four further trials were performed, all failed to demonstrate a significant advantage of OFS (ABCSG-12 (22), IBCSG 1193 (23), INT0101 (24, 25), Zipp(26)) (Table V).

The ABSCG-12 Trial examined the effect of adding Zolendronic acid, a bisphosphonate that acts by slowing down bone resorption, to a combination of either Goserelin 
Table III. Trial Outcomes for AI.

\begin{tabular}{|c|c|c|c|c|c|c|}
\hline Study & Tx Arms & DFS HR (CI) & TTR HR (CI) & $\begin{array}{c}\text { TTDR/DRFI/DRFS/ } \\
\text { DDFS HR (CI) }\end{array}$ & $\begin{array}{c}\mathrm{BCFI} / \mathrm{BCFS} \\
\mathrm{HR}(\mathrm{CI})\end{array}$ & OS HR (CI) \\
\hline \multicolumn{7}{|l|}{ Mono-therapy } \\
\hline ATAC (14) & $\begin{array}{c}\text { A } v s . \mathrm{T} v s \\
\text { T\&A }\end{array}$ & $\begin{array}{c}0.91(0.83-0.99) \\
p=0.04 \\
\mathrm{ER}+0.86(0.78-0.95) \\
p=0.003\end{array}$ & $\begin{array}{c}0.84(0.75-0.93) \\
p=0.001 \\
\mathrm{ER}+0.79(0.70-0.89) \\
p=0.0002\end{array}$ & $\begin{array}{c}0.87(0.77-0.99) \\
p=0.03 \\
\mathrm{ER}+0.85(0.73-0.98) \\
p=0.02\end{array}$ & $\mathrm{n} / \mathrm{a}$ & $\begin{array}{c}0.97(0.88-1.08) \\
p=0.6 \mathrm{ER}+ \\
0.95(0.84-1.06) \\
p=0.4\end{array}$ \\
\hline BIG 1-98 $(3,18)$ & $\mathrm{L} v s . \mathrm{T}$ & $\begin{array}{c}0.53(0.78-0.96) \\
p=0.007\end{array}$ & $\mathrm{n} / \mathrm{a}$ & $\begin{array}{c}0.86(0.74-0.998) \\
p=0.047\end{array}$ & $\begin{array}{c}0.86(0.76-0.98) \\
p=0.03\end{array}$ & $\begin{array}{c}0.87(0.77-0.999) \\
p=0.048\end{array}$ \\
\hline TEAM (38) & $\begin{array}{l}\text { Upfront } \\
\text { E } v s . \mathrm{T}\end{array}$ & $\begin{array}{c}0.89(0.77-1.03) \\
p=0.12\end{array}$ & $\mathrm{n} / \mathrm{a}$ & $\mathrm{n} / \mathrm{a}$ & $\mathrm{n} / \mathrm{a}$ & $\mathrm{n} / \mathrm{a}$ \\
\hline \multicolumn{7}{|l|}{ Sequential } \\
\hline IES (52) & $\begin{array}{l}\mathrm{T} \text { to } \mathrm{E} \\
v s . \mathrm{T}\end{array}$ & $\begin{array}{c}0.81(0.72-0.91) \\
p<0.001\end{array}$ & $\mathrm{n} / \mathrm{a}$ & $\begin{array}{c}0.84(0.73-0.97) \\
p=0.01\end{array}$ & $\begin{array}{c}0.81(0.71-0.92) \\
p<0.001\end{array}$ & $\begin{array}{c}0.53(0.75-0.99) \\
p<0.04\end{array}$ \\
\hline ARNO $(7,53)$ & $\begin{array}{l}\mathrm{T} \text { to } \mathrm{A} \\
v s . \mathrm{T}\end{array}$ & $0.66(0.44-1.0)$ & $\mathrm{n} / \mathrm{a}$ & $\mathrm{n} / \mathrm{a}$ & $\mathrm{n} / \mathrm{a}$ & $\begin{array}{c}0.53(0.28-0.99) \\
p=0.045\end{array}$ \\
\hline ABCSG Trial & $\mathrm{T}$ to $\mathrm{A}$ & $0.91(0.75-1.103)$ & $0.8(0.631-1.013)$ & $0.78(0.60-0.99)$ & $\mathrm{n} / \mathrm{a}$ & $0.87(0.64-1.16)$ \\
\hline $8(7,54)$ & $v s . \mathrm{T}$ & $p=0.33$ & $p=0.06$ & $p=0.046$ & & $p=0.33$ \\
\hline ITA $(55)$ & $\begin{array}{l}\mathrm{T} \text { to } \mathrm{A} \\
v s . \mathrm{T}\end{array}$ & $\mathrm{n} / \mathrm{a}$ & $\begin{array}{c}0.64(0.44-0.94) \\
p=0.02\end{array}$ & $\mathrm{n} / \mathrm{a}$ & $\begin{array}{c}0.72(0.44-1.17) \\
p=0.2\end{array}$ & $\begin{array}{c}0.79(0.52-1.21) \\
p=0.3\end{array}$ \\
\hline BIG 1-98 $(3,18)$ & $\begin{array}{l}\mathrm{L} \text { to } \mathrm{T} \\
\text { vs. } \\
\mathrm{T} \text { to } \mathrm{L}\end{array}$ & $\begin{array}{c}1.06(0.91-1.23) \\
p=0.48 \\
1.07(0.92-1.25) \\
p=0.36\end{array}$ & N/A & $\begin{array}{c}1.14(0.92-1.42) \\
p=0.24 \\
1.23(0.99-1.53) \\
p=0.06\end{array}$ & $\begin{array}{c}1.10(0.91-1.32) \\
p=0.34 \\
1.16(0.96-1.40) \\
p=0.12\end{array}$ & $\begin{array}{c}0.97(0.80-1.19) \\
p=0.79 \\
1.10(0.90-1.33) \\
p=0.36\end{array}$ \\
\hline TEAM (38) & $\begin{array}{l}\text { E vs. } \\
\text { T to E }\end{array}$ & $\begin{array}{c}1.06(0.91-1.24) \\
p=0.42\end{array}$ & $\begin{array}{c}1.06(0.88-1.28) \\
p=0.53\end{array}$ & $\mathrm{n} / \mathrm{a}$ & $\mathrm{n} / \mathrm{a}$ & $\begin{array}{c}1.0(0.89-1.14) \\
p>0.99\end{array}$ \\
\hline \multicolumn{7}{|l|}{ Extended } \\
\hline MA-17 $(5,56)$ & $\begin{array}{l}\mathrm{L} v s . \\
\text { Placebo }\end{array}$ & $\begin{array}{c}0.68(0.56-0.83) \\
p<0.001\end{array}$ & $\mathrm{n} / \mathrm{a}$ & $\begin{array}{c}0.81(0.63-1.04) \\
p=0.09\end{array}$ & $\mathrm{n} / \mathrm{a}$ & $\begin{array}{c}0.99(0.79-1.24) \\
p=0.83\end{array}$ \\
\hline $\begin{array}{l}\text { ABCSG Trial } \\
6(40)\end{array}$ & $\begin{array}{l}\text { A } v s . \\
\text { no Tx }\end{array}$ & $\mathrm{n} / \mathrm{a}$ & $\begin{array}{c}0.62(0.40-0.96) \\
\quad p=0.031\end{array}$ & $\begin{array}{c}0.53(0.29-0.96) \\
p=0.034\end{array}$ & $\mathrm{n} / \mathrm{a}$ & $\begin{array}{c}0.89(0.59-1.34) \\
p=0.57\end{array}$ \\
\hline $\begin{array}{l}\text { NSABP - } \\
33(41)\end{array}$ & $\begin{array}{c}\text { E vs. } \\
\text { Placebo }\end{array}$ & $0.68 p=0.07$ & $0.44, p=0.004$ & $\mathrm{n} / \mathrm{a}$ & $\mathrm{n} / \mathrm{a}$ & $\mathrm{n} / \mathrm{a}$ \\
\hline
\end{tabular}

A, Anastrozole; AI, aromatase inhibitor; BCFI, breast cancer-free interval; BCFS, breast cancer-free survival; CI, confidence interval (all 95\%); DDFS, distant disease-free survival; DFS, disease-free survival; DRFI, distant relapse-free interval; DRFS, distant relapse-free survival; E, Exemestane; HR, hazard ratio; L, Letrozole; OS, overall survival; T, Tamoxifen; Tx, treatment; TTR, time to recurrence; TTDR, time to distant relapse.

and Tamoxifen or Goserelin and Anastrozole in premenopausal women with endocrine-responsive early breast cancer for 3 years. After a median follow-up of 47.8 months there was no significant difference in DFS between the Anastrozole and Tamoxifen groups (HR for disease progression in the Anastrozole group, 1.10; 95\% CI 0.78 to $1.53 ; p=0.59)(22)$.

The INT0101 trial included a comparison of chemotherapy alone vs. chemotherapy followed by 5 years of Goserelin vs. chemotherapy followed by 5 years of Goserelin plus Tamoxifen. The study demonstrated a greater benefit with the combined therapy following chemotherapy with a statistically significant improvement in DFS, but not OS $(24,25)$.
Similarly, the Zipp trial compared Goserelin ('Zoladex') $v s$. Tamoxifen $v s$. combination treatment, however failed to demonstrate a significant difference between the treatment modalities (26).

In 2003, International Breast Cancer Study Group (IBCSG) with the collaboration of the Breast International Group (BIG) and The North American Breast cancer Group initiated the SOFT \& TEXT trials (27). In the SOFT trial, ovarian function suppression in premenopausal women with ER-positive breast cancer was examined to determine if the treatment combination with AI has any DFS benefits over Tamoxifen alone or Tamoxifen with OFS $(20,28)$. OFS was determined by patient choice between Triptorelin (a GNRH agonist) administration, oophorectomy, or ovarian irradiation 
Table IV. Trials for sequential AI therapy.

\begin{tabular}{|c|c|c|c|c|}
\hline Study & Patients & Detail & Follow up & Outcome \\
\hline IES (52) & 4724 & $\begin{array}{c}- \text { Tam } 2 y \text { to Exemestane } 3 y \\
- \text { Tam } 5 y\end{array}$ & 91 months & -Switch improved DFS \\
\hline ARNO $95(7,53)$ & 979 & $\begin{array}{c}\text {-Tam } 2 \mathrm{y} \text { to earsabears } \\
- \text { Tam } 5 \mathrm{y}\end{array}$ & 30.1 months & -Switch improved DFS \\
\hline ABCSG Trial 8 (7) & 3714 & $\begin{array}{c}- \text { Tam 5y } \\
\text {-Tam 2y to Anastrazole 3y }\end{array}$ & 60 months & $\begin{array}{c}\text {-Switch Improved DFS \& RFS, } \\
\text {-Superior to Tam }\end{array}$ \\
\hline ITA (55) & 448 & $\begin{array}{c}\text {-Tam 2-3y to Anastrazole } 5 y \\
\text {-Tam } 5 y\end{array}$ & 128 months & $\begin{array}{c}\text {-Switch improved DFS \& RFS } \\
\text {-Superior to Tam }\end{array}$ \\
\hline BIG 1-98 $(3,18)$ & 8010 & $\begin{array}{c}\text {-Letrozole 5y } \\
\text {-Tam 5y } \\
\text {-Letrozole to Tamoxifen } \\
\text {-Tamoxifen to Letrozole }\end{array}$ & $8.1 \mathrm{y}$ & $\begin{array}{l}\text {-No difference between switching } \\
\text { and Letrozole alone } \\
\text {-superior to Tam }\end{array}$ \\
\hline TEAM (38) & 9779 & $\begin{array}{l}\text {-Exemestane } \\
\text {-Tamoxifen } \\
\text {-Tam to exemestane }\end{array}$ & $5.1 \mathrm{y}$ & $\begin{array}{c}\text {-Improved DFS, } \\
\text {-No sig diff between switching } \\
\text { and Exemestane alone, } \\
\text {-Superior to Tam. }\end{array}$ \\
\hline MA-17 $(5,56)$ & 5187 & $\begin{array}{l}\text { 4-6y Tam then } \\
\text {-Letrozole } \\
\text {-placebo }\end{array}$ & 64 months & Improved DFS \\
\hline ABCSG Trial 6a (40) & 856 & $\begin{array}{c}\text { 5y Tam } \\
\text {-Anastrozole 3y } \\
\text {-no further treatment }\end{array}$ & 62.3 months & Improved RFS \\
\hline NSABP -33 (41) & 1598 & $\begin{array}{c}5 y \text { Tam -Exemestane } 5 y \\
\text { vs. placebo }\end{array}$ & 30 months & Improved DFS \\
\hline
\end{tabular}

DFS, Disease-free survival; RFS, recurrence-free survival; Tam, Tamoxifen; Y, years.

(27). Patients in SOFT who underwent neoadjuvant or adjuvant chemotherapy were randomised, once a premenstrual level of oestradiol was confirmed, within 8 months after completion of chemotherapy. In the TEXT trial, Triptorelin was used for chemical ovarian suppression. If chemotherapy was indicated, it was given in combination with Triptorelin and then, endocrine therapy was administered after the completion of chemotherapy. Patients were randomised to receive Tamoxifen and Triptorelin $v s$. Exemestane and Triptorelin. Patients that were not indicated to receive chemotherapy, commenced endocrine therapy 6-8 weeks post initiation of Triptorelin, in order to enable a time interval for ovarian oestrogen to decline.

Combining the two trials, there were analysed 4690 patients of whom $42.6 \%$ did not receive chemotherapy, $57.4 \%$ received chemotherapy after randomisation in the TEXT trial and $23.2 \%$ received chemotherapy pre randomisation in the SOFT group (27).

After a median follow up of 68 months, DFS was observed to be significantly higher in the Exemestane and OFS group compared to the Tamoxifen and OFS group $91.1 \%$ vs. $87.3 \%$. Freedom from recurrence was reported as 92.8\% with Exemestane and OFS vs. $88.8 \%$ in the Tamoxifen and OFS group. Despite this statistically significant difference in DFS and recurrence rates, there was no difference in OS between the two groups (27).

Concerning patients who did not require chemotherapy, possibly due to better prognostic factors such as node negative, grade 1 small tumours, $97.6 \%$ and $97.5 \%$ of them remained disease-free at year 5 in TEXT and SOFT, respectively. This may suggest that there is a group of women that have an excellent prognosis benefiting from highly effective adjuvant endocrine therapy alone with no added benefit from OFS $(21,28)$. It is noted that the median age of this group was 46 (closer to menopausal age) (20). Interestingly, the addition of OFS in patients under Tamoxifen therapy was associated with reduction in recurrence rates, $14.5 \%$ in patients not receiving chemotherapy and $15.9 \%$ in patients that had chemotherapy (27).

It is noteworthy to highlight that within this study a subset of patients who were aged less than 35 and had chemotherapy, showed better outcomes after treatment with Exemestane plus ovarian suppression (21). The 5-year breast cancer-free rates were $83.4 \%$ with Exemestane and OFS $v s$. 78.9\% Tamoxifen and OFS vs. 67.7\% Tamoxifen alone. This corresponded to a 5-year breast cancer recurrence of 1 in 6 women having an AI and OFS compared to 1 in 3 women taking Tamoxifen only (21) (Table VI). 
Table V. The role of ovarian suppression.

\begin{tabular}{|c|c|c|c|c|}
\hline Year & Author & Study & Outcome & Evidence \\
\hline 1882 & Nunn (57) & Case study & Breast cancer regression once postmenopausal & $\begin{array}{l}\text { Level V } \\
\text { Case study }\end{array}$ \\
\hline 1889 & Schinzinger (58) & Review & Oophorectomy for advanced disease and prophylaxis & $\begin{array}{c}\text { Level V } \\
\text { Proposed theory }\end{array}$ \\
\hline 1896 & Beatson (58) & Case Study & $\begin{array}{l}\text { Oophorectomy in a metastatic patient } \\
\text { possibly in luteal phase of cycle }\end{array}$ & $\begin{array}{l}\text { Level V } \\
\text { Case study }\end{array}$ \\
\hline 1897 & Boyd (58) & Case Series & Oophorectomy for adjuvant treatment 5 cases & Level IV \\
\hline 1952 & Huggins (59) & Case Study & Adrenalectomy for mammary cancer & Level V \\
\hline 1959 & Paterson (60) & Randomised Trial & A randomized trial for ovarian ablation in early breast cancer & Level II \\
\hline 1996 & $\begin{array}{c}\text { EBCTCG } \\
(13,60,61)\end{array}$ & MetaAnalysis & $\begin{array}{c}12 \text { randomised trials, } 3456 \text { women, OFS or OA } v s \text {. } \\
\text { control. OA alone reduces recurrence and increases } \\
\text { survival for node positive and negative women aged }<50 \text {. } \\
15 \text { y survival } 52.4 \% \text { vs. } 46.1 \% \\
6.3 / 100 \text { fewer deaths } \\
\text { OA equivalent to either chemotherapy or Tam }\end{array}$ & Level I \\
\hline 2005 & INT $0101(25)$ & Randomised Trial (US) & $\begin{array}{c}1503 \text { premenopausal women: --chemotherapy } \\
\text {-Goserelin } 5 \text { y } \\
\text {-Goserelin \& Tam } \\
\text { Improvement in DFS but not OS }\end{array}$ & Level I \\
\hline 2006 & ZIPP (26) & Observational study & $\begin{array}{c}2706 \text { women, } \\
\text {-Tam vs. Goserelin } v s \text {. Tam and Goserelin combined } \\
\text { Goserilin provided significant benefit of event-free } \\
\text { survival after median follow up } 5.5 \text { years }\end{array}$ & Level II-III \\
\hline 2009 & ABSCG - $12(22)$ & $\begin{array}{l}\text { Randomized Controlled } \\
\text { Multicentre Trial }\end{array}$ & $\begin{array}{l}\text { Anastrozole } v s \text {. Tam with and without Zolendronic acid } \\
\text { No benefit between the two arms }\end{array}$ & Level I \\
\hline 2015 & SOFT (27) & Phase 3 RCT & $\begin{array}{l}\text { Tam alone } v s . \text { Tam \& OS } v s . \text { Exemestane \& OS } \\
\text { No diff between Tam and OS } v s . \text { Tam alone }\end{array}$ & Level I \\
\hline 2015 & TEXT (27) & Phase 3 RCT & $\begin{array}{c}\text { Tam \& OFS } v s . \text { Exemestane \& OFS } \\
\text { DFS Exemestane \&OFS } 91 \% \\
\text { Superior to Tam \& OFS }\end{array}$ & Level I \\
\hline
\end{tabular}

OA, Ovarian ablation; DFS, disease-free survival; OS, overall survival; Tam, Tamoxifen; OFS, ovarian function suppression.

A second subset of patients that was also identified as benefiting from $\mathrm{AI}$ and OFS treatment, were the patients that received chemotherapy but remained pre-menopausal. The median age within this group was 40 years (20). The 5-year breast cancer-free rate for an AI \& OFS was $85.7 \%$ compared to $82.5 \%$ with Tamoxifen and OFS $v s .78 \%$ for patients only on Tamoxifen. Therefore, there was a $35 \%$ relative risk reduction in cancer recurrence with an AI plus OFS therapy compared to Tamoxifen alone, and a $22 \%$ relative risk reduction of cancer recurrence for Tamoxifen plus OFS vs. Tamoxifen alone (21).

Interestingly, patients with HER2-positive tumours appeared to gain no benefit from OFS and AI compared to Tamoxifen and OFS (28). This might again direct treatment towards Tamoxifen for this specific subgroup of patients, though further trials are necessary $(28,29)$.

ASCO published new guidelines in 2016 for OFS therapy. They produced an evidence-based recommendation, according to which high risk ER-positive pre-menopausal women should undergo OFS in addition to standard adjuvant treatment, but low risk patients would not benefit. High risk patients were defined as women with stage II or stage III breast cancer, who would ordinarily be recommended to receive adjuvant chemotherapy and women with stage I or II breast cancers that would be considered for chemotherapy. Five-year treatment was advised on the basis that all trials analysed had a 5-year duration with no other comparable data. ASCO stated that there is no role for OFS in ER-negative tumours and that either an AI or tamoxifen is recommended as the adjuvant endocrine therapy to be used alongside OFS (30).

\section{Evidence for Extended Endocrine therapy}

The rationale for extended endocrine therapy beyond 5 years is due to hormone-positive breast cancer recurrence risk continuing indefinitely. Although detectable breast cancer can be removed surgically, there might be present undetectable microdeposits that after many years could 
Table VI. Evidence for $O S \& A I(27)$.

\begin{tabular}{|c|c|c|c|c|c|c|c|}
\hline AI \& OS & & $\begin{array}{c}\text { DFS } 5 \text { y } \\
\%, \text { HR }(\mathrm{CI}) \\
p \text {-value }\end{array}$ & $\begin{array}{l}\text { Risk for } \\
\text { recurrence }\end{array}$ & $\begin{array}{c}\text { Free from } \\
\text { BC at } \\
5 \text { years }\end{array}$ & $\begin{array}{c}\text { Recurrence } \\
\text { at a } \\
\text { distant site }\end{array}$ & $\begin{array}{c}\text { Freedom from } \\
\text { distant } \\
\text { recurrence }\end{array}$ & OS \\
\hline \multicolumn{8}{|l|}{ Chemo } \\
\hline TEXT & $\mathrm{E} \& \mathrm{OFS} v s$ & $0.69(0.53-0.90)$ & - & - & - & - & - \\
\hline SOFT & T \& OFS & $0.84(0.62-1.13)$ & & & & & \\
\hline \multicolumn{8}{|l|}{ No Chemo } \\
\hline TEXT & E \& OFS $v s$ & $0.54(0.32-0.92)$ & - & $97.6 \%$ & - & - & - \\
\hline SOFT & $\mathrm{T} \& \mathrm{OvS}$ & $0.68(0.38-1.19)$ & & $97.5 \%$ & & & \\
\hline Combined & $\mathrm{T} \& \mathrm{OFS}$ & $87.3 \%(85.7-88.7)$ & $0.66(0.55-0.80)$ & $88.8 \%$ & $6.9 \%$ & $92 \%(90.7-93.1)$ & $96.9 \%(96-97.6)$ \\
\hline \multirow{3}{*}{$(21,27)$} & E \& OFS & $91.1 \%(89.7-92.3)$ & $p<0.001$ & & $0.78(0.62-0.97)$ & $93.8 \%(92.7-94.8)$ & $95.9 \%(94.9-96.7)$ \\
\hline & & HR $0.72(0.6-0.85)$ & & $92.8 \%$ & $p=0.02$ & $0.78(0.62-0.97)$ & $p=0.03$ \\
\hline & & $p<0.001$ & & & & $p=0.02$ & $1.14(0.86-1.51)$ \\
\hline
\end{tabular}

AI, Aromatase inhibitor; BC, breast cancer; E, Exemestane; HR, hazard ratio; OS, overall Survival; OFS ovarian function suppression; T, Tamoxifen.

Table VII. The Role of Extended Tamoxifen Therapy.

\begin{tabular}{|c|c|c|c|c|}
\hline Study & Patients & Treatments & DFS HR (CI) & OS HR (CI) \\
\hline ATLAS (35) & 6846 & Tam $10 \mathrm{y}$ & $\begin{array}{l}\qquad 5-90.90(0.79-1.02) p=0.1 \\
\quad>10 \text { y RR } 0.75, p=0.01 \\
\text { Absolute reduction at } 15 \text { y } 3.7 \%\end{array}$ & $\begin{array}{c}\text { BC Mortality 5-RR } 0.97(0.79-1.18) p=0.74 \\
\text { Mortality }>10 \text { y RR } \\
0.71(0.58-0.88) p=0.002\end{array}$ \\
\hline ATTom (36) & 6953 & Tam for $10 \mathrm{y}$ & $\begin{array}{l}0.85(0.76-0.95) p=0.003) \\
\text { Absolute reduction } 4 \%\end{array}$ & $\begin{array}{c}\text { BC Mortality }-5-9 \text { y } 1.08(0.85-1.38) \\
>10 \text { y } 0.75(0.63-0.90) p=0.007\end{array}$ \\
\hline Pooled analysis (37) & 17477 & Tam $10 \mathrm{y} v s .5 \mathrm{y}$ & $\mathrm{n} / \mathrm{a}$ & $\begin{array}{c}\text { BC mortality } 5-9 \text { y } 0.97(0.84-1.15) \\
\text { BC mortality >10y } 0.75(0.65-0.86) p=0.00004 \\
\text { BC Mortality all years } 0.85(0.77-0.94) p=0.001\end{array}$ \\
\hline
\end{tabular}

BC, Breast cancer; HR, hazard ratio; N/A, not applicable; RR, relative risk; Tam, Tamoxifen; Y, year.

develop into clinically-apparent disease i.e. recurrence. This may in time lead to reduced OS in some cases (31).

Initial studies assessing the extended use of Tamoxifen were the ECOG (32), Scottish Trial (33), and NSABP B-14 (34). In total, 1,588 patients were included, but there was not observed any advantage of 10 years over the 5 years of Tamoxifen treatment period. According to this, it was suggested that the extended use if Tamoxifen increased the occurrence of side effects with no concomitant therapeutic advantage $(7,34)$.

The NSABP B-14 was the first study to assess the benefit of continuing adjuvant Tamoxifen beyond 5 years. The study included 1152 ER-positive breast cancer patients, who, following completion of Tamoxifen, were randomised to a further 5-year vs. no further treatment. The trial however was closed prematurely in the first interim with no benefit noted from extended treatment. The DFS at 4 years was $92 \%$ compared to $86 \%$ in the 10 years arm and the reason was attributed to the agonistic action of Tamoxifen (34).

More recently, The ATLAS study (Tables III, VII), confirmed that there was a benefit to patients receiving 10 years of Tamoxifen (35). In this study, 12894 women from 36 countries were enrolled, who had already taken Tamoxifen for 5 years randomised to either continuing the Tamoxifen for a further 5-year treatment (6,846 women) or stopping their treatment. The study showed a significant reduction in recurrence (3.7\% reduction) and breast cancer specific mortality in the treatment group (12.2\% vs. $15 \%)$. Specifically, breast cancer mortality was similar for both groups up to year 9; however, in years 10-14 there was a significant reduction in the extended treatment group. The study concluded that women with ER-positive tumours who remained premenopausal at the end of 5 years should receive a further 5-year Tamoxifen treatment (35). 
The UK aTTom Trial (Tables III and VII), recruited 6539 women with early ER-positive breast cancer, who, like in the ATLAS study, had received 5 years of Tamoxifen and were then randomised to having a further 5-year or no further treatment. This study demonstrated benefits 7-10 years post diagnosis with a $2 \%$ reduction in mortality and absolute reduction of $4 \%$ with longer treatment (36).

Both these trials, when combined (Table III), have suggested a $50 \%$ reduction in mortality risk when receiving further Tamoxifen treatment compared to no further treatment. In conclusion, these two studies provided the evidence that significant reductions in breast cancer mortality and improvements in OS are demonstrated after 10 years of Tamoxifen treatment. These two studies are considered the predominant source of evidence for extended Tamoxifen use based upon the combined number of patients which outnumbered the NSABP B-14 study (37).

In the MA-17 study (Tables III and IV), Goss et al. examined switching from Tamoxifen to Letrozole in postmenopausal women who had already completed 5 years of Tamoxifen (5). In a randomized, double blinded, placebo controlled trial of Letrozole versus a placebo to be given for a five year period. The MA-17 study was unblinded and stopped 1 year earlier than planned after an interim analysis suggesting that 5 years of Tamoxifen followed by a switch to 5 years of Letrozole produced an improvement in both disease free and distant DFS but no difference to OS. Although there was no significant difference in the OS there was an apparent survival advantage seen if the patient had taken Tamoxifen for more than 5 years (5). The reasons for this were contemplated by Goss et al., particularly in view of the trial by Coombs for switching to Exemestane after only 2-3 years of Tamoxifen (38). The MA17 study also went on to look at premenopausal women taking Letrozole, who had undergone either bilateral oophorectomy or were permanently amenorrheic following chemotherapy or Tamoxifen treatment. They noted that the patients on Letrozole benefited from extended adjuvant endocrine treatment (5). Importantly the MA-17 trial concluded that Letrozole as extended adjuvant therapy achieved a significant improvement in OS in women with node-positive disease. Mortality was reduced by $39 \%$ among the approximately 2,500 women with node-positive disease randomized in the study. The MA-17 trial showed extended adjuvant therapy with Letrozole to be a welltolerated protection against the continuing risk of breast cancer recurrence for thousands of women receiving standard adjuvant Tamoxifen (39).

Further evidence to support the benefits of extended endocrine therapy was illustrated in the Australian Breast and Colorectal Study Group (ABCSG) trial 6A (Tables III and IV). The ABCSG evaluated adding 3 years of Anastrazole vs. no further treatment in postmenopausal women with ER-positive breast cancer, who have received 5 years of Tamoxifen treatment and continued to be disease-free. After a median follow up of 62.3 months the risk of recurrence was noted to be reduced by $38 \%$ in the extended treatment arm compared to no further treatment $(\mathrm{HR}=0.62[95 \% \mathrm{CI}=0.4-0.96])$. Furthermore, OS was noted to be equal between both arms (40).

Although the NSABP-33 study (Tables III, IV), was designed to examine the benefits of extended endocrine therapy with Exemestane in postmenopausal women that had received 5 years of Tamoxifen, the trial was closed following the results of the MA-17 and BIG 1-97 trials. Despite this, they revealed a 4-year improvement in DFS and relapse-free survival (41).

Until recently, there was no evidence to support extended therapy with AI beyond 5 years (3). This issue has been addressed in the MA17R (42). Goss et al. conducted a double blinded trial of Letrozole versus placebo for 5 years in patients that had previously received an AI for 4.5-6 years. The primary end-point was DFS. The 5-year DFS rate was $95 \%$ in Letrozole group versus $91 \%$ in placebo group with the results stratified according to the nodal status, the prior adjuvant chemotherapy, the interval from the last dose of AI therapy, and the duration of treatment with Tamoxifen. They therefore concluded that extended AI for 10 years resulted in increased DFS but their results did not show any improvement in OS when compared to the placebo group. In this study, 1,918 patients were recruited, of which 1,369 had more than 5 years of Tamoxifen before their initial 5 years of AI therapy. Therefore, a majority of these patients received approximately 15 years of hormone therapy overall. Whilst this study provided useful conclusions about extended AI therapy, it should be taken in context of patients initially being on Tamoxifen. The authors alluded to this in the discussion and stated that only $21 \%$ patients in MA17R did not recieve prior Tamoxifen therapy. Many post-menopausal patients were started on AI therapy for 5 years, and the impact of extended AI therapy was also demonstrated. Improved DFS and equivocal OS were seen in this study whilst also demonstrating safety e.g. in terms of bone health, by extending the AI. However, it is noteworthy to mention that only approximately $20 \%$ of participants fall into this group.

MA17R is currently the only published trial assessing extended AI therapy. Three other trials are currently in process and due to be published soon $(43,44,45)$. Preliminary data for these 3 trials has been presented at 2016 San Antonio Breast Cancer Symposium. Five years of Letrozole therapy after 5 years of endocrine treatment in the National Surgical Adjuvant Breast and Bowel Project (NSABP) B-42 trial, did not significantly improve DFS or OS (43). It did however conclude a significantly improved breast cancerfree interval event rate and distant recurrence rate (43). The DATA study looked at 6 versus 3 additional years of Anastrozole, after 2 to 3 years of adjuvant Tamoxifen and did not demonstrate improved rates of DFS (44). Five versus 2.5 years of Letrozole after 5 years of endocrine therapy in 


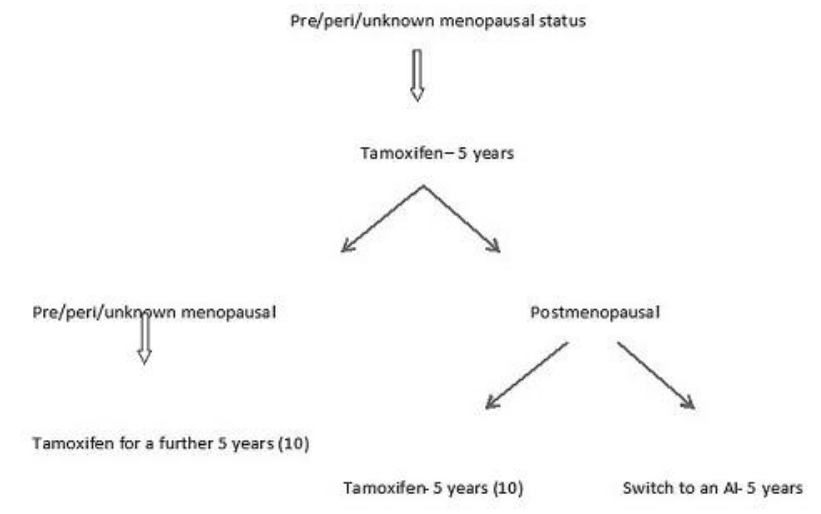

Figure 1. Recommendation 1: for premenopausal women commencing adjuvant endocrine therapy.

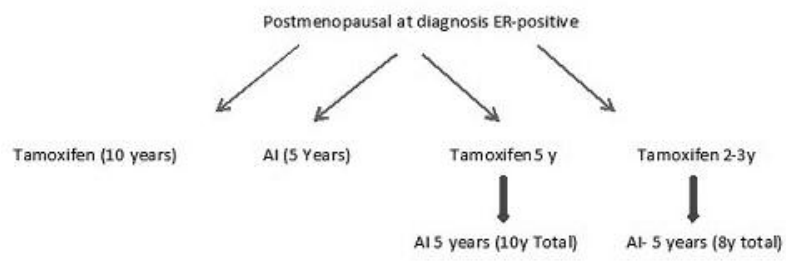

Figure 2. Recommendation 2: for postmenopausal women commencing adjuvant endocrine therapy.

the IDEAL trial did not improve DFS (45). The full studies once published should help refine further the value of extended AI treatment and suggest more therapeutic strategies to the different groups of breast cancer patients.

\section{Discussion}

In 2010, ASCO released adjuvant endocrine therapy guidance to clinicians supported with the evidence available at that time. The guidelines were based upon a systematic review from 2007-2009 which identified 12 prospective randomized control trials (46). It was evident that the reviewed trials had limitations including different timing of randomisation, their short follow up, their differing populations with some only recruiting patients free of recurrence and multiple years of Tamoxifen use (46).

In 2014, in view of recent trials and new evidence emerging, the ASCO guidelines have been updated (Figures 1-3). Although 5 studies were reviewed, Eastern Cooperative Oncology Group (ECOG) (32), Scottish Cancer Trials Breast Group (33), NSABP B-14 (34), ATLAS (35) and aTTom (36), generally the recommendations appear to be supported

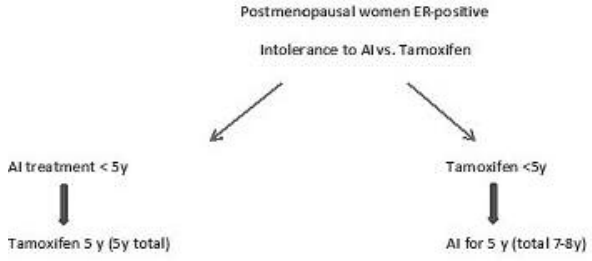

Figure 3. Recommendation 3: for postmenopausal women intolerant to adjuvant endocrine therapy.

by the two larger more recent randomized trials than the older three studies that were identified (3).

The 2014 ASCO guidelines provided guidance regarding when extended adjuvant endocrine therapy should be offered. It has been recommend that extending Tamoxifen therapy from 5 years to 10 will lower the recurrence risk, and improve breast cancer and OS rates $(3,35,36)$. Three of the 5 trials demonstrated improvement in overall mortality, which was not demonstrated in the National Surgical Adjuvant Breast and bowel Project (NSABP B14) (34). Despite this both the aTTom and ATLAS with extended Tamoxifen monotherapy demonstrated a reduced risk of breast cancer recurrence, again not demonstrated in either the NSABP B14 or the Scottish Trial (33-36). In particular the aTTom Trial noted a small but statistically significant reduction in recurrence by year 7-9 and 10-14 years of extended monotherapy $(3,35,36)$ (Table III).

The question is why there was a difference between the trials. Two theories have been postulated, the first is the "carry over effect" of Tamoxifen having a continual effect despite cessation of treatment. This relates to the impact of Tamoxifen in the progression of late stage precursor lesions, creating a transient delay until presentation of a breast cancer. The second relates to OS requiring a longer follow up period to assess patient's survival with and without recurrence (47).

It is essential to highlight that the choice of extended adjuvant endocrine therapy is still determined by menopausal status. In general, if the patient is pre/peri or unknown menopausal status the patient should receive Tamoxifen for an additional 5 years (46). Following this period, the patient's menopausal status should be reviewed. This is where difficulties arise. While on Tamoxifen many women either stop menstruating or develop irregular menses. A menopausal venous blood screen is not always accurate having been on a course of Tamoxifen. The question that arises when considering extended endocrine therapy is if patients should continue on Tamoxifen for further 5 years or switch Tamoxifen to an AI for an additional 5 years. It is suggested that if there is any doubt about menopausal status, the patients should persist and proceed to take extended Tamoxifen for 10 years due to the extended benefit 
demonstrated in the ATLAS Trial $(3,35)$. Goss et al. in the Ma-17 trial, defined menopausal as being aged at least 50 when commencing Tamoxifen, had undergone bilateral oophorectomy, were $<50$ on commencing Tamoxifen but stopped menses secondary to Tamoxifen or chemotherapy, or their hormone profile revealed postmenopausal status (5). In agreement with the SOFT and TEXT trial, if a woman was close to menopausal age at the start of her 5 years of Tamoxifen then they could be considered for switching to an AI, whereas those patients most likely to remain premenopausal should be considered for 10 years of Tamoxifen therapy with OFS or consider an AI with OFS $(21,27)$.

The MA17R study conclusions help define further the option of extended AI adjuvant therapy for patients who are post-menopausal at the start of their adjuvant endocrine therapy (42). NSABP-42, DATA, and IDEAL trials when published will help further to assess the impact of extended AI therapy (43-45).

An important factor that should be taken into consideration whenever contemplating extended therapy is the occurrence of side effects. Each patient needs to be assessed on an individual basis taking into account their prior co-morbidities, and potential risks from extended treatment. It is suggested that reviewing each patient on their merits with a full discussion regarding both risks and benefits of extended adjuvant endocrine monotherapy with Tamoxifen. The side effects of Tamoxifen are well documented; consequently the risks of endometrial cancer or thromboembolism may well be increased with extended treatment (13). Certainly, the trials used to produce the ASCO recommendations did suggest a consensus regarding these risks $(3,35,46)$. In the ATLAS study with extended Tamoxifen therapy they noted an increase in uterine cancer and thromboembolic events, but a reduced risk of strokes and ischaemic heart disease (35). The aTTom study noted a significant increase in endometrial cancer events (36). Despite this, based on the studies examined extended Tamoxifen did not appear to impact on non-breast cancer mortality rates (3).

In the ATAC trial, Anastrazole was found to be more tolerable for patients when compared to Tamoxifen in postmenopausal ladies (17). Although we appreciate as these are two different agents their side effects may well differ. They both cause menopausal symptoms (hot flushes and excessive sweats) but they each have their own specific adverse effects. With AI this is musculoskeletal, osteoporosis, fractures, cardiac events $(3,5)$. The MA-17 study, revealed that sideeffects such as hot flashes, anorexia, arthralgia, myalgia and alopecia were significantly higher in patients taking Letrozole. Accompanying this there were greater number of patients diagnosed with osteoporosis, fractures, and cardiovascular disease $(3,5)$. However, the statistical significant difference was only noted with osteoporosis. Despite this, the number of breast cancer deaths in the
Letrozole group this was reviewed concluding no causal relationship between the deaths and Letrozole $(5,27)$.

In the BIG 1-98 study, $13.6 \%$ of patients discontinued Letrozole treatment early compared to $11.9 \%$ taking Tamoxifen with the majority suffering adverse events within the first 2 years of treatment then plateauing to $1-2 \%$ per year (19).

The other consideration is patient non-compliance with the adjuvant monotherapy endocrine treatment (Figure 3 ). The average patient compliance is approximately $80 \%$ (2). The side effects of the medication are the main factor for noncompliance, but also other factors have been identified including no oncological follow up, extremes of age (patient refusal), and being followed up by their family doctor $(2,5)$.

This again can be noted in the SOFT and TEXT trials. Any additional therapy has associated cost and associated toxicity. At 5 years, $30.2 \%$ of the patients were still receiving some $v s$. all protocol treatments (27), 56.1\% had completed treatment and only $13.7 \%$ had stopped treatments early, $16.1 \%$ in the Exemestane group compared to $11.2 \%$ in the Tamoxifen group (27). Not only do these young patients have the side effects from the AI or the Tamoxifen, but also the added toxicity of the ovarian suppression: menopausal symptoms, sexual functioning (Vaginal dryness, loss of libido) and depression (approx. 50\%) (21). If the side effects are too extreme then compliance with the treatment stops. Therefore, there has to be a fine balance and each patient should be fully informed of the side effects, the available alternative options, and the concerns of non-compliance outlined from the start.

In the SOFT/TEXT trial, $30.6 \%$ in the Exemestane group reported grade 3-4 adverse events such as hot flushes, musculoskeletal symptoms, hypertension and depression compared to only $29.4 \%$ in the Tamoxifen group, similar to post-menopausal ladies in comparative studies. Within the Exemestane group, fractures, musculoskeletal aches, vagina dryness, decreased libido and dyspareunia were more frequently reported compared to thromboembolic effects, hot flushes, sweating and urinary incontinence in the Tamoxifen group (27). Overall, however, neither type of hormone therapy was shown to be superior to the other type in terms of quality of life (27).

In order for a treatment to be beneficial there has to be a balance between the benefit and the toxicity, noting that some side effects can be long-lasting and make an extreme impact on the younger patient group. Bianchini et al. in 2013, proposed that the ideal candidate for extended adjuvant therapy would be a patient whose breast cancer has both high proliferation and expression of ER (48). We may well be able to offer a new treatment option for premenopausal women or those undertaking extended therapy, but we need to ensure the patients are well informed of the adverse effects, with support and advice available, in order to ensure compliance for the intended outcomes to be achieved.

The emergence of new technologies utilising certain biomarkers might help to predict recurrence risk and guide 
future endocrine therapy. The Breast Cancer Index (BCI) is a multi-gene test that identifies the two gene ratio HOXB13:IL17BR (H/I) and the Molecular Grade Index (MGI). A higher distant recurrence-free survival is associated with a low BCI score and is considered as a prognostic value for late recurrence (49). In addition, in TransATAC (translational arm of the Arimidex, Tamoxifen, alone or in combination trial) trial the 21-gene recurrence score assay and the immunohistochemical prognostic model, IHC4, have been shown to be prognostic for early distant recurrence (50). Oncotype Dx prognostic assay is also starting to suggest a subset of patients that might benefit from endocrine therapy alone (51). Furthe $\backslash r$ studies and validation of such biomarkers utilisation is needed to personalise endocrine therapy for breast cancer patients.

\section{Conclusion}

On deciding which adjuvant treatment and duration, extended endocrine therapy should be tailored according to patients needs dictated by their individual risk factors, molecular type of breast cancer, tumour size, nodal status and risk of recurrence, menopausal status, co-morbidities and lifestyle. Clinicians ought to discuss with patients the pros and cons of different adjuvant endocrine therapy approaches and highlight the potential side effects and toxicity. The MA17 study, promoted switching from Tamoxifen to Letrozole in post-menopausal women, while the ATLAS \& aTTom trials recommend extended 10 year Tamoxifen treatment, the TEXT and SOFT trials suggest that an AI with ovarian suppression in some premenopausal patients is associated with significant survival advantages. These latter two studies do offer premenopausal women with ER-positive breast cancer a further treatment option, demonstrated to reduce recurrence and be beneficial for women with higher risk disease in order to maximise their therapeutic gain with consideration toward treatment compliance despite the challenging side effects from the AI. MA17R promotes extended AI adjuvant therapy for post-menopausal women; however, preliminary results from upcoming studies do not show a great advantage in patients, pursuing this option and the full results of these studies are highly anticipated.

\section{References}

1 Schnitt SJ: Classification and prognosis of invasive breast cancer: from morphology to molecular taxonomy. Modern Pathology 23(Suppl 2S): 60-64, 2010.

2 Burstein HJ, Temin S, Anderson H, Buchholz TA, Davidson NE, Gelmon KE, Giordano SH, Hudis CA, Rowden D, Solky AJ, Stearns V, Winer EP and Griggs JJ: Adjuvant endocrine therapy for women with hormone receptor-positive breast cancers: American Society of Clinical Practice Guideline focussed update. J Clin Oncol 32: 1-16, 2014.
3 The Breast International Group (BIG) 1-98 Collaborative Group, Thürlimann B, Keshaviah A, Coates AS, Mouridsen H, Mauriac L, Forbes JF, Paridaens R, Castiglione-Gertsch M, Gelber RD, Rabaglio M, Smith I, Wardley A, Price KN and Goldhirsch A: Comparison of Letrozole and Tamoxifen in postmenopausal women with early breast cancer. N Engl J Med 353: 2747-2757, 2005.

4 Early Breast Cancer Trialists Collaborative Group: Effects of chemotherapy and hormonal therapy for early breast cancer on recurrence and 15 year survival: an overview of the randomized trials. Lancet 365: 1687-1717, 2005.

5 Goss PE, Ingle JN, Martino S, Robert NJ, Muss HB, Piccart MJ, Castiglione M, Tu D, Shepherd LE, Pritchard KI, Livingston RB, Davidson NE, Norton L, Perez EA, Abrams JS, Cameron DA, Palmer MJ and Pater JL: Randomized trial of Letrozole following Tamoxifen as extended adjuvant therapy in receptor positive breast cancer: Updated Findings from NCIC, CTG, MA17. J Natl Cancer Inst 97: 1262-1271, 2005.

6 Early Breast Cancer Trials Collaborative Group: Relevance of breast cancer hormone receptors and other factors to the efficacy of adjuvant Tamoxifen: Patient level meta-analysis of randomised trials. Lancet 378: 771-784, 2011.

7 Jakesz R, Jonat W, Gnant M, Mittlboeck M, Greil R, Tausch C, Hilfrich J, Kwasny W, Menzel C, Samonigg H, Seifert M, Gademann G, Kaufmann M and Wolfgang J: Switching of Postmenopausal Women with Endocrine Responsive Early Breast Cancer to Anastrazole after 2 Years' Adjuvant Tamoxifen: Combined Results of ABCSG Trial 8 and ARNO 95 Trial. Lancet 366: 455-462, 2005.

8 Nolvadex Adjuvant Trial Organisation: Controlled trial of tamoxifen as an adjuvant agent in management of early breast cancer. Lancet 1: 257-261, 1983.

9 Swedish Breast Cancer Cooperative Group: Randomized trial of two versus five years of adjuvant tamoxifen for postmenopausal early stage breast cancer. J Natl Cancer Inst 88: 1543-1549, 1996.

10 'Nolvadex' Adjuvant Trial Organisation: Controlled trial of tamoxifen as adjuvant agent in the management of early breast cancer. Br J Cancer 57: 608-611, 1988.

11 CRC Adjuvant Breast Trial Working Party: Cyclophosphamide and Tamoxifen as adjuvant therapies in the management of breast cancer. Br J Cancer 57: 604-607, 1998.

12 Fisher B, Jeong JH Bryant J, Anderson S, Dignam J, Fisher ER and Wolmark N: Treatment of lymph node negative, oestrogen -receptor positive breast cancer: long term findings from the National Surgical Adjuvant Breast and Bowel Project randomised clinical trials. Lancet 364: 858-868, 2004.

13 Early Breast Cancer Trialists' Collaborative Group: Tamoxifen for early breast cancer: an overview of the randomised trials. Lancet 351: 1451-1467, 1998.

14 Baum M, Budzar AU, Cuzick J, Forbes J, Houghton JH, Klijn JG and Sahmoud T: Anastrazole alone or in combination with tamoxifen versus tamoxifen alone for adjuvant treatment of postmenopausal women with early breast cancer: first results of the ATAC randomised trial. Lancet 359: 2131-2139, 2002.

15 Fisher B, Jeong JH, Bryant J, Anderson S, Dignam J, Fisher ER and Wolmark N: treatment of lymph node negative, oestrogen receptor positive breast cancer: long term findings from The National Surgical Adjuvant Breast and Bowel Project Randomised Clinical Trials. Lancet 364: 858-868, 2004.

16 Baum M, Buzdar A Cuzick J, Forbes J, Houghton J, Howell A and Sahmoud T: Anastrazole alone or in combination with 
tamoxifen versus tamoxifen alone for adjuvant treatment of postmenopausal women with early breast cancer: results of the ATAC (Arimidex, Tamoxifen, Alone or in Combination) trial efficacy and safety update analyses. Cancer 98: 1802-1810, 2003.

17 Howell A, Cuzick J Baum M, Buzdar A, Dowsett M, Forbes JF, Hoctin-Boes G, Houghton J, Locker GY and Tobias JS: Results of the ATAC (Arimidex, Tamoxifen, Alone or in Combination) trial after completion of 5 years' adjuvant treatment for breast cancer. Lancet 365: 60-62, 2005.

18 The BIG 1-98 Collaborative Group: Letrozole therapy alone or in sequence with tamoxifen in women with breast cancer. N Engl J Med 361: 766-776, 2009.

19 Colleoni M, Giobbie-Hurder A, Regan MM, Thürlimann B, Mouridsen H, Mauriac L, Forbes JF, Paridaens R, Láng I, Smith I, Chirgwin J, Pienkowski T, Wardley A, Price KN, Gelber RD, Coates AS and Goldhirsch A: Analysis adjusting for selective crossover show improved overall survival with adjuvant Letrozole when compared to Tamoxifen in the BIG 1-98 study. J Clin Oncol 29: 1117-1124, 2011.

20 Bliss J, Kilburn LS, Coleman RE, Forbes JF, Coates AS, Jones SE, Jassem J, Delozier T, Andersen J, Paridaens R, van de Velde CJ, Lønning PE, Morden J, Reise J, Cisar L, Menschik T and Coombes RC: Disease-related outcomes with long-term followup: An updated analysis of the intergroup Exemestane study. J Clin Oncol 30: 709-717, 2012.

21 San Antonio Breast Cancer Symposium (SABCS): Abstract S308: Presented December 11, 2014.

22 Gnant M, Mlineritsch B, Schippinger W, Luschin-Ebengreuth G, Pöstlberger S, Menzel C, Jakesz R, Seifert M, Hubalek M, Bjelic-Radisic V, Samonigg H, Tausch C, Eidtmann H, Steger G, Kwasny W, Dubsky P, Fridrik M, Fitzal F, Stierer M, Rücklinger E and Greil R, ABCSG - 12 Trial Investigators: endocrine therapy plus Zolendronic acid in premenopausal breast cancer. N Engl J Med 360: 679-691, 2009.

23 Paridaens RJ, Gelber S, Cole BF, Gelber RD, Thürlimann B, Price KN, Holmberg SB, Crivellari D, Coates AS and Goldhirsch A: Adjuvant on-line estimation of chemotherapy effectiveness when added to ovarian function suppression plus Tamoxifen for premenopausal women with estrogen receptor positive breast cancer. Breast Cancer Res Treat 123: 303-10, 2010.

24 Krop IE and Winer EP: Ovarian Suppression for Breast Cancer: An Effective Treatment in search of a Chance. J Clin Oncol 23: 5869-5872, 2005.

25 Davidson NE, O'Neill AM, Vukov AM, Osborne CK, Martino S, White DR and Abeloff MD.: Chemo-endocrine therapy for premenopausal women with axillary lymph node positive, steroid hormone receptor positive breast cancer: Results from 0101(E5188). J Clin Oncol 23: 5973-5982, 2005.

26 Baum M, Hackshaw A, Houghton J, Rutqvist, Fornander T, Nordenskjold B, Nicolucci A and Sainsbury R: Adjuvant Goserelin in pre-menopausal patients with early breast cancer: Results for the ZIPP Study. Eu J Cancer 42: 95-904, 2006.

27 Pagani O, Regan MM, Walley BA, Fleming GF, Colleoni M, Láng I, Gomez HL, Tondini C, Burstein HJ, Perez EA, Ciruelos E, Stearns V, Bonnefoi HR, Martino S, Geyer CE Jr, Pinotti G, Puglisi F, Crivellari D, Ruhstaller T, Winer EP, Rabaglio-Poretti M, Maibach R, Ruepp B, Giobbie-Hurder A, Price KN, Bernhard J, Luo W, Ribi K, Viale G, Coates AS, Gelber RD, Goldhirsch A and Francis PA: Adjuvant Exemestane with ovarian suppression in premenopausal breast cancer. N Engl J Med 371: 107-118, 2014.
28 Amoroso V, Berruti A and Simoncini E: Exemestane with ovarian suppression in premenopausal breast cancer. NEJM 371: 1357, 2014.

29 Lowe RR, Duc NB, Havighurst TC, Mohsin SK, Zhang Q, DeMets DL and Allred DC: Her-2/neu overexpression and response to oophorectomy plus Tamoxifen adjuvant therapy in estrogen receptor positive premenopausal women with operable breast cancer. J Clin Oncol 21: 453-457, 2003.

30 Burnstein HJ, Lacchetti C, Anderson H, Buchholz TA, Davidson NE, Gelmon KE, Giordano SH, Hudis CA, Solky AJ, Stearns V, Winer EP and Griggs JJ: Adjuvant endocrine therapy for women with hormone receptor-positive breast cancer: American Society of Clinical Oncology clinical practice guideline update on ovarian suppression. J Clin Oncol 34: 1689-1703, 2016.

31 Early Breast Cancer Trialists' Collaborative Group: Tamoxifen for early breast cancer. Cochrane Database Syst Rev 1: CD000486, 2001.

32 Tormey DC, Gray R and Falkson HC: Post chemotherapy adjuvant Tamoxifen therapy beyond 5 years in patients with lymph node positive breast cancer. Eastern Cooperative oncology Group J Natl Cancer Inst 88: 1828-1833, 1996.

33 Stewart HJ, Forrest AP, Everington D, McDonald CC, Dewar JA, Hawkins RA, Prescott RJ and George WD: Randomised comparison of 5 years of adjuvant Tamoxifen with continuous therapy for operable breast cancer. The Scottish Cancer trials Breast Group. Br J Cancer 74: 297-299, 1996.

34 Fisher B, Dignam J, Bryant J and Wolmark N: Five versus more than five years of Tamoxifen for lymph node-negative breast cancer: updated findings from the National Surgical Adjuvant Breast and Bowel Project B-14 randomized trial. J Natl Cancer Inst 93: 684-690, 2001.

35 Davies C, Pan H, Godwin J, Gray R, Arriagada R, Raina V, Abraham M, Medeiros Alencar VH, Badran A, Bonfill X, Bradbury J, Clarke M, Collins R, Davis SR, Delmestri A, Forbes JF, Haddad P, Hou MF, Inbar M, Khaled H, Kielanowska J, Kwan WH, Mathew BS, Mittra I, Müller B, Nicolucci A, Peralta O, Pernas F, Petruzelka L, Pienkowski T, Radhika R, Rajan B, Rubach MT, Tort S, Urrútia G, Valentini M, Wang Y and Peto $\mathrm{R}$ : Long Term effects of continuing adjuvant Tamoxifen to 10 years versus stopping at 5 years after diagnosis of oestrogen receptor positive breast cancer: ATLAS, A Randomized Trial. Lancet 381: 805-816, 2013.

36 Gray RG, Rea D, Bowden SJ, Perry P, Earl HM, Poole CJ, Bates T, Chetiyawardana S, Dewar JA, Fernando IN, Grieve R, Nicoll J, Rayter Z, Robinson A, Salman A, Yarnold J, Bathers A, Marshall A and Lee M: aTTom: Long term effects of continuing adjuvant Tamoxifen to 10 years versus stopping at 5 years in 6953 women with early breast cancer. JCO 31: (s5), 2013.

37 Jankowitz RC and Davidson NE: Adjuvant endocrine therapy for breast cancer: How long is enough? Oncology 27: 1-4, 2013.

38 Coombs RC, Hall E, Gibson LJ, Paridaens R, Jassem J, Delozier T, Jones SE, Alvarez I, Bertelli G, Ortmann O, Coates AS, Bajetta E, Dodwell D, Coleman RE, Fallowfield LJ, Mickiewicz E, Andersen J, Lønning PE, Cocconi G, Stewart A, Stuart N, Snowdon CF, Carpentieri M, Massimini G and Bliss JM and van de Velde C: A Randomized Trial of Exemestane After 2-3 years of Tamoxifen therapy in post-menopausal women with primary breast cancer. N Engl J Med 350: 1081-1092, 2004.

39 Goss P: Preventing relapse beyond 5 years: the MA.17 extended adjuvant trial. Semin Oncol 33: S8-12, 2006. 
40 Jakesz R, Greil R, Gnant M, Schmid M, Kwasny W, Kubista E, Mlineritsch B, Tausch C, Stierer M, Hofbauer F, Renner K, Dadak $\mathrm{C}$, Rücklinger E and Samonigg H: Extended adjuvant therapy with Anastrozole among postmenopausal breast cancer patients: results from the randomized Austrian Breast and Colorectal Cancer Study Group Trial 6a. Natl Cancer Inst 99: 1845-1853,2007.

41 Mamounas EP, Jeong JH, Wickerham DL, Smith RE, Ganz PA, Land SR, Eisen A, Fehrenbacher L, Farrar WB, Atkins JN, Pajon ER, Vogel VG, Kroener JF, Hutchins LF, Robidoux A, Hoehn $\mathrm{JL}$, Ingle JN, Geyer CE Jr, Costantino JP and Wolmark N: Benefit from Exemestane as extended adjuvant therapy after 5 years of adjuvant Tamoxifen: intention-to-treat analysis of the National Surgical Adjuvant Breast And Bowel Project B-33 trial. J Clin Oncol 26: 1965-1971, 2008.

42 Goss PE, Ingle JN, Pritchard KI, Robert NJ, Muss H, Gralow J, Gelmon K, Whelan T, Strasser-Weippl K, Rubin S, Sturtz K, Wolff AC, Winer E, Hudis C, Stopeck A, Beck JT, Kaur JS, Whelan K, Tu D and Parulekar WR: Extending aromatase-inhibitor adjuvant therapy to 10 years. N Engl J Med 375: 209-219, 2016.

43 Mamounas EP, Bandos H, Lembersky BC, CE Geyer, Fehrenbacher L, Graham ML, Chia SL, Brufsky A, Hennessy BT, Soori GS, Dakil SR, Seay TE, Wade JL, McCarron EC, Paik S, Swain SM, Wickerham DL and Wolmark N: A randomized, double-blinded, placebo-controlled clinical trial of extended adjuvant endocrine therapy with letrozole in postmenopausal women with hormone-receptor-positive breast cancer who have completed previous adjuvant treatment with an aromatase inhibitor. 2016 San Antonio Breast Cancer Symposium. Abstract S1-05:Presented December 7, 2016.

44 Tjan-Heijnen VC, Van Hellemond IE, Peer PG, Swinkels AC, Smorenburg CH, Van der Sangen M, Kroep JR, De Graaf H, Honkoop AH, Erdkamp F, Van den Berkmortel FW, Kitzen JJ, De Boer M, De Roos WK, Linn SC, Imholz AL and Seynaeve C: First results from the multicenter phase III DATA study comparing 3 versus 6 years of anastrozole after 2-3 years of tamoxifen in postmenopausal women with hormone receptorpositive early breast cancer. 2016 San Antonio Breast Cancer Symposium. Abstract S1-03:Presented December 7, 2016.

45 Blok EJ, Van de Velde CJH, Meershoek-Klein Kranenbarg EM, Putter H, van den Bosch J, Maartense E, van Leeuwen-Stok AE, Liefers G-J, Nortier JWR, Rutgers EJT and Kroep JR: Optimal duration of extended letrozole treatment after 5 years of adjuvant endocrine therapy. San Antonio Breast Cancer Symposium. Abstract S1-04:Presented December 7, 2016.

46 Burstein HJ, Prestrud AA, Seidenfeld J, Anderson H, Buchholz TA, Davidson NE, Gelmon KE, Giordano SH, Hudis CA, Malin J, Mamounas EP, Rowden D, Solky AJ, Sowers MR, Stearns V, Winer EP, Somerfield MR and Griggs JJ: American society of clinical oncology clinical practice guideline: Update on adjuvant endocrine therapy for women with hormone receptor positive breast cancer. J Clin Oncol 28: 1-22, 2010.

47 Cuzick J: Duration of aromatase inhibitor treatment in breast cancer: The role of the "carryover" effect. Oncology 27: 1224-1225, 2013.

48 Bianchini and Gianni L: An unmet need: Tailoring Extended adjuvant endocrine therapy. BJC 109: 2951-2953, 2013.

49 Zhang Y, Schnabel CA, Schroeder BE, Jerevall PL, Jankowitz RC, Fornander T, Stål O, Brufsky AM, Sgroi D and Erlander MG: Breast cancer index identifies early stage oestrogen receptor positive breast cancer patients at risk for early and late distant recurrence. Clin Cancer Res 19: 4196-4205, 2013.
50 Sgroi DC, Sestak I, Cuzick J, Zhang Y, Schnabel CA, Schroeder B, Erlander MG, Dunbier A, Sidhu K, Lopez-Knowles E, Goss $\mathrm{PE}$ and Dowsett M: Prediction of the late distant recurrence in patients with oestrogen receptor positive breast cancer: a prospective comparison of the breast cancer index (BCI) assay, 21 gene recurrence score, and IHC4 in the TransATAC study population. Lancet Oncol 14: 1067-1076, 2013.

51 Dowsett M, Sestak I, Lopez-Knowles E, Sidhu K, Dunbier AK, Cowens JW, Ferree S, Storhoff J, Schaper C and Cuzick J: Comparison of PAM50 risk of recurrence score with Oncotype Dx and IHC4 for predicting risk of distant recurrence after endocrine therapy. J Clin Oncol 31: 2783-2790, 2013.

52 Bliss JM, Kilburn LS, Coleman RE, Forbes JF, Coates AS, Jones SE, Jassem J, Delozier T, Andersen J, Paridaens R, van de Velde CJ, Lønning PE, Morden J, Reise J, Cisar L, Menschik T and Coombes RC: Disease related outcomes with long term follow up: an updated analysis of the intergroup Exemestane Study. J Clin Oncol 30: 709-717, 2012.

53 Kauffman M, Jonat W, Hilfrich J, Eidtmann H, Gademann G, Zuna I and von Minckwitz G: Improved overall survival in postmenopausal women with early breast cancer after Anastrozole initiated after treatment with Tamoxifen compared with continued Tamoxifen: the ARNO 95 Study. J Clin Oncol 25: 2664-2670, 2007.

54 Dubsky PC, Jakesz R, Mlineritsch B, Pöstlberger S, Samonigg H, Kwasny W, Tausch C, Stöger H, Haider K, Fitzal F, Singer CF, Stierer M, Sevelda P, Luschin-Ebengreuth G, Taucher S, Rudas M, Bartsch R, Steger GG, Greil R, Filipcic L and Gnant M: Tamoxifen and Anastrazole as a sequencing strategy: a randomised controlled trial in postmenopausal patients with endocrine responsive early breast cancer from the Austrian Breast and Colorectal Cancer Study Group. J Clin Oncol 30: 722-728, 2012.

55 Boccardo F, Guglielmini P, Bordonaro R, Fini A, Massidda B, Porpiglia M, Roagna R, Serra P, Orzalesi L, Ucci G and Rubagotti A: Switching to Anastrazole versus continue Tamoxifen treatment of early breast cancer: long term results of the italian Tamoxifen Anastrozole trial. Eur J Cancer 49: 1546-1554, 2013.

56 Goss PE, Ingle JN, Martino S, Robert NJ, Muss HB, Piccart MJ, Castiglione M, Tu D, Shepherd LE, Pritchard KI, Livingston RB, Davidson NE, Norton L, Perez EA, Abrams JS, Therasse P, Palmer MJ and Pater JL: A randomized trial of Letrozole in postmenopausal women, after 5 years of Tamoxifen therapy for early-stage breast cancer. N Engl J Med 349: 1793-1802, 2003.

57 Nunn T: On Cancer of the breast. London, UK: J \& A Churchill; 1882.

58 Love RR and Philips J: Oophorectomy for breast cancer: history re-visited. J Natl Cancer Inst 94: 1433-1434, 2002.

59 Huggins $\mathrm{C}$ and Ling-Yuan Dao T: Adrenalectomy for mammary cancer: surgical tecnic of bilateral one-stage adrenalectomy in man. Ann Surg 136: 595-603, 1952.

60 Early Breast Cancer Trialists' Collaborative Group: polychemotherapy for early breast cancer: An overview of the randomised trials. Lancet 352: 930-942, 1998.

61 Goss P: Preventing relapse beyond 5 years: the MA.17 extended adjuvant trial. Semin Oncol 33(2 Suppl 7): S8-12, 2006.

Received July 26, 2017

Revised September 2, 2017

Accepted September 7, 2017 